\title{
Genetic tolerance to Ceratocystis wilt in melina (Gmelina arborea Roxb.)
}

\author{
Dawa Méndez-Álvarez', Olman Murillo-Gamboa ${ }^{1 *}$, Yorleny Badilla-Valverde', William Hernán- \\ dez-Castro
}

\begin{abstract}
${ }^{1}$ Instituto Tecnológico de Costa Rica; School of Forest Engineering; P.O. Box: 159-7050 Cartago-Costa Rica.
${ }^{2}$ Instituto de Investigaciones y Servicios Forestales; Facultad de las Ciencias de la Tierra y el Mar; Universidad Nacional; P.O. Box: 86-3000 Heredia-Costa Rica.
\end{abstract}

* Corresponding author: OIman Murillo-Gamboa, email: olmuga@yahoo.com

\begin{abstract}
Gmelina arborea is the second most planted tree species in Costa Rica, and one of the most important in several Latin American countries. In recent years, a disease caused by Ceratocystis fimbriata, has spread throughout Latin America, leading to the complete root of the tree in a few months. This study was conducted to evaluate the incidence, severity and genetic tolerance control of the Ceratocystis wilt in G. arborea. Data is based on a 2.4-year-old clonal trial, with 34 elite genotypes, at Río Jiménez, Guácimo in the Costa Rican Caribbean region. The variables diameter at breast height $(\mathrm{DBH})$, total height, disease incidence and disease severity were evaluated. A pathogenicity index was proposed as a new selection criterion. SELEGEN (EMBRAPA) software was used for the evaluation of the genetic control in all traits investigated. Overall incidence rate was $39 \%$ and severity was $13 \%$. Mean clonal heritability for severity was $h^{2} \mathrm{mc}=0.59$ and for incidence $h^{2} \mathrm{mc}=$ 0.47 , these values were high evidencing that both traits are under a strong genetic control. The pathogenicity index becomes a useful discrimination criterion for ranking genotypes by their disease tolerance. An infection pattern inversely proportional to the DBH was observed. Although none of the 34 genotypes evaluated recorded total resistance to $C$. fimbriata, eight of these genotypes show strong genetic tolerance to the disease, and high productivity. Their use can be encouraging and will contribute to the reduction of Ceratocystis wilt impact in the country, as well as in the tropical Latin America region.
\end{abstract}

Keywords: breeding, clonal forestry, genetic resistance, pathology, tropical disease.

\section{Introduction}

Gmelina arborea (melina) is a large to medium-sized deciduous tree, native to the tropical and subtropical regions of Asia and widely planted in the tropical regions of America, Asia, and Africa (Pathala et al., 2015). It is the second most widely planted tree species in Costa Rica, with a wide commercial demand in Ecuador and Colombia as well, and subjected to breeding programs in Costa Rica (Lokmal 1994; Hogde \& Dvorak 2004; Kumar 2007; Murillo et al., 2016). Its importance lies in its rapid growth rate, high productivity and wide tolerance to site conditions (Ávila et al., 2016), as well as its wide use of wood in industry (Moya 2004).

Despite its growth potential and economic value, melina is susceptible to a number of diseases in plantations (Anuagasi et al., 2017). So far, diseases of most concern in America are vascular wilts caused by Ceratocystis fimbriata in Brazil and Ecuador, as well as the death of melina in Costa Rica (Oliveira et al., 2015; Arguedas et al., 2018), which was recently reported to be caused by C. fimbriata (Méndez et al., 2020). The incidence of this disease in Costa Rica is estimated at a rate of $40 \%$ in commercial plantations (Arguedas et al., 2018).

Among the symptoms that can be observed are, wilt and leaf loss, sprouting on the stem at the base of the tree, trunk rot with cankers and exudations, necrotic spots inside the stem and finally, tree death (Salas et al., 2016b; Arguedas et al., 2018; Méndez et al., 2020). This disease has been observed to occur at seven months age in plantations, and severely reduces growth and development, causing serious economic losses (Murillo et al., 2016). 
C. fimbriata is a saprophytic fungus present in soils and a primary pathogen in angiosperms and gymnosperms (Harrington et al. 2014). It is distributed in tropical, subtropical and temperate regions of the world (Holland et al. 2019). C. fimbriata is capable of infecting at least 31 species from 14 economically important families (Holland et al. 2019; Valdetaro et al. 2015). Species of the genus Ceratocystis have various means of transmission and dispersal, including insects, wind, water, root grafts, and pruning tools; infecting its host generally through wounds (Ferreira et al. 2010; Harrington et al. 2011). In Costa Rica, there is evidence of a relationship between disease incidence and site conditions; according to Arguedas et al (2018), there is higher incidence in plantations with high stand density and soils with higher clay content. However, the etiology of the diseases has not been established yet (Méndez et al., 2020).

Effective disease management in forest plantations relies on multidisciplinary collaboration and dynamic approaches (He et al., 2016). In tree breeding programs, the selection of individuals with a clear disease resistance pattern or tolerance is usually sought. These should be properly determined based on parameters associated with effective genetic control, such as genotypic variation, heritability values, genetic ranking, among others (Telford et al., 2014; Salas et al., 2016a).

Therefore, clonal selection based on genetic tolerance against a specific disease, can not only increase timber production in the next plantations, but will also contribute to a better stand density management, with an important economic impact for producers (Salas et al., 2016a). One of the first steps to be taken is the determination of disease incidence and severity in the breeding population. Genetic collections should be screened in order to determine their degree of tolerance or resistance. Several approaches can be implemented, which could be classified as direct (based on pathogen inoculation) and indirect (based on field trials) methods.

The indirect method is based on field measurements in genetic tests established in different sites, which have previously been identified as highly contagious with this disease (Salas et al., 2016a; Murillo et al., 2016). Despite not being a completely safe method, it allows screening and showing a first selection criterion in the breeding population (Telford et al., 2014; He et al., 2016). Since polygenic resistance is often more durable than monogenic resistance, it has been suggested that breeding strategies should take these criteria into account (Palloix et al., 2009).

Therefore, an extensive melina breeding program has been launched through the Tree Breeding Cooperative GENFORES in several countries in Latin America, with the intention of searching for the genetic variation related to resistance to $C$. fimbriata. In addition to breeding efforts, other management approaches need to be incorporated in the global strategy against diseases. Since the greater the number of breakthrough resistance factors, the greater the number of virulence mutations required in the pathogen genome and, the less likely their occurrence (Palloix et al., 2009). The main objective of the present study was to determine whether there is a genetic control of tolerance to "Ceratocystis wilt", in a clonal trial established in the Costa Rican Caribbean region.

\section{Materials and Methods}

A 2.4 years-old melina clonal trial was evaluated, established in Río Jiménez of Guácimo, Caribbean region (10.251356 'N, -83.576124' W), in a semi-flooded area, on an inceptisol soil (Alvarado et al., 2014). The trial was established in April 2016, under a good weed control, but without land preparation, as it was previously planted with crops. About two tons_ha-1 of calcium carbonate was applied on site along the tree planting lines. In the second year, a first commercial thinning was performed on $33 \%$ of the population. The trial site belongs to the very humid premontane forest life zone of the Holdridge classification, with a precipitation ranging from 3500-4600 mm year ${ }^{-1}$, no drought period and a mean annual temperature of $26^{\circ} \mathrm{C}$.

The clonal test was established following a randomized complete block experimental design developed by GENFORES (Murillo et al., 2019). Within the six blocks, 34 elite genotypes were tested, each represented by two pairs of ramets randomly distributed within each block, with the restriction of not planting two pairs of the same clone together. Thus, 24 plants in the entire trial represented each genotype. Commercial seed from the best local seed orchard was used as a control lot. Trees were planted at $4 \times 4 \mathrm{~m}$ spacing. All trees were measured for $\mathrm{DBH}$ $(1.3 \mathrm{~m})$ and total height with a telescopic pole.

\section{Disease severity and incidence determination}

Disease incidence was assessed by binomial scoring of all individual trees, as healthy (without symptoms $=0$ ) or sick (with visible symptoms $=1$ ). Both general and clonal incidence, were determined by equation 1 (Cavallini, 1998):

$$
\text { Incidence }=\frac{\text { Total number of affected trees }}{\text { Total number of trees }} * 100
$$

Based on the severity scale proposed by Salas et al. (2016a, $2016 \mathrm{~b}$ ) trees were scored in four categories from " 1 " to " 4 ". Where the value of " 1 " was assigned to a completely healthy tree or with no visible symptoms. While a value of "4" was assigned to a completely dead tree, with no foliage, no bark and dark stem. With this record, the severity index (Equation 2) was determined for each of the 34 test clones, based on the evaluation of all its individual trees.

$$
\text { Severity index }=\frac{N_{1} \times 1+N_{2} \times 2+N_{3} \times 3+N_{4} \times 4}{N_{1}+N_{2}+N_{3}+N_{4}}
$$

Where,

$\mathrm{N}_{1}$ = number of trees (ramets) of a given clone "i" with a score of 1 or healthy, with no visible disease symptoms;

$\mathrm{N}_{2}$ = number of trees (ramets) of a given clone "i" scored by 2 or with some visible disease symptoms like obvious leaf wilt; the stem may have small necrotic wounds with black exudation in locations other than pruning sites; sprouts break may initiate. Not all symptoms are expressed;

$\mathrm{N}_{3}$ = number of trees (ramets) of a given clone "i" scored by 3 with more than 2 visible disease symptoms such as canker lesions on the bark with signs of rot, bark exposure and bulging, 
prominent exudation; loss of more than $50 \%$ of the leaf area in a progressive pattern; sprouts developed;

$\mathrm{N}_{4}$ = number of trees (ramets) of a given clone "i" scored by 4 or completely dead.

A pathogenicity index was determined on a scale of 1 to 100 (Equation 3), for the entire assay, as well as for each clone in the trial, where the value of 100 corresponds to a completely healthy population.

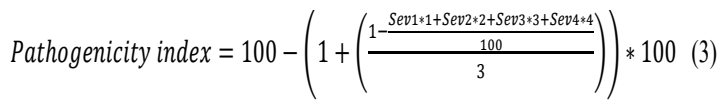

Where,

Sev1 corresponds to the number of trees (ramets) of a given clone " $\mathrm{i}$ " rated with severity " 1 " or completely healthy;

Sev2 corresponds to the number of trees (ramets) of a given clone " $\mathrm{i}$ " rated with severity " 2 " or with some visible disease symptoms, such as obvious leaf wilt; the stem may have small necrotic wounds with black exudation;

Sev3 corresponds to the number of trees (ramets) of a given clone " $\mathrm{i}$ " rated with severity " 3 " or visibly diseased, with more than $50 \%$ loss of the leaf area and signs of rot;

Sev4 corresponds to the number of trees (ramets) of a given clone "i" qualified as " 4 " or completely dead.

A genetic ranking of this pathogenicity index was obtained using SELEGEN software (Resende, 2016), which provided a list of all 34 clones, from the highest (more tolerant) to the lowest (least tolerant). The range of values was subdivided into three thirds, to facilitate their interpretation as high, medium and low tolerant.

\section{Genetic control analysis}

Genetic test was planted following GENFORES's experimental design, which is a randomized complete block (RCB) design, with six blocks per trial site. Each block is composed of four ramets (plants) per clone, arranged in two non-contiguous pairs, randomly distributed within the block. The clones within blocks were considered as the experimental unit (plot). Therefore, 24 plants (ramets) represented each clone. After 30 days, the test was replanted to reduce mortality and imbalance.

Genetic analysis of DBH, total height, incidence, severity and pathogenicity index, were performed with SELEGEN software (Resende, 2016). Data were analyzed with model 4 (equation 4), which is specific for genetic tests under a completely random block design, in a single location, with unrelated clones and several ramets per clone in the experimental unit.

$$
y=X r+Z g+W p+e
$$

Where:

" $y$ " is a data vector, " $r$ " is a vector of repetition effects (assumed as fixed) and added to the general mean; "a" is a vector of individual additive genetic effects (assumed as random), " $p$ " is a vector of plot effects assumed as random, and " $\mathrm{e}$ " is a vector of residuals or the error term (random). Capital letters represent incidence matrices for the mentioned effects. From the analysis, it was determined the following variance components and parameters for each of the traits investigated: genetic variance among clones $\left(\sigma_{g}^{2}\right)$, plot variance $\left(\sigma_{p l o t}^{2}\right)$, environmental variance $\left(\sigma_{e}^{2}\right)$, total phenotypic variance $\left(\sigma_{p}^{2}\right)$, individual $\left(H_{g}^{2}\right)$ and mean $\left(H_{m(\text { clonal })}^{2}\right)$ clonal broad sense heritabilities, coefficient of determination for the plot effect (block $x$ family) $\left(C_{\text {plot }}^{2}\right)$; It accounts for variances among plots within blocks, selective accuracy ( $A$ ), assuming complete survival, individual additive genetic variation coefficient $\left(C V_{g i}(\%)\right)$, genotypic variation coefficient among clones $\left(C V_{g}(\%)\right)$, environmental variation coefficient variation $\left(C V_{e}(\%)\right.$ ), relative variation coefficient $\left(C V_{r}\right)$, standard deviation and the variance of the error term by,

$$
\begin{aligned}
& \sigma_{p}^{2}=\sigma_{g}^{2}+\sigma_{p l o t}^{2}+\sigma_{e}^{2}, \\
& H_{g}^{2}=\sigma_{g}^{2} / \sigma_{p}^{2}, \\
& H_{m(\text { clonal })}^{2}=\sigma_{g}^{2} /\left\{\sigma_{p}^{2}+\left(\sigma_{p l o t}^{2} / 6\right)+\left[\left(\sigma_{a w}^{2}+\sigma_{e}^{2}\right) / 24\right]\right\},
\end{aligned}
$$
assuming complete survival, " 6 " is the number of replications, " 4 " is the number of trees within each plot $(n=4)$, then 24 is the total number of effective ramets of each other in test. $C_{\text {plot }}^{2}=\sigma_{\text {plot }}^{2} / \sigma_{p}^{2}$, it assumes complete survival, " 6 " is the number of replications $(r=6)$, " 4 " is the number of trees within each $n \operatorname{nt}(n-1)$ than 24 is the total number of effective trees in test. $A=\sqrt{h_{m(\text { clone })}^{2}}$, accuracy of clonal selection assuming complete survival.

To proceed with selection of genotypes scenarios, the genetic ranking of Pathogenicity Index and DBH growth were graphically compared, as suggested by Murillo et al. (2019). Each of the two ranking was divided into three thirds: high, medium and low performance. Subdivisions were obtained by (the difference between highest-lowest value)/3, as described by Resende et al. (2018). Finally, a deviance analysis was performed, as suggested by Murillo et al. (2019), to determine the existence of significant differences among genotypes.

\section{Results}

The mean DBH was $18.89 \mathrm{~cm}(9.5 \mathrm{~cm} /$ year $)$ and the mean total height was $14.95 \mathrm{~m}(7.5 \mathrm{~m} /$ year) at 2.4 years-old, with a predominant diameter distribution between 15 to $25 \mathrm{~cm}$. Only eight individuals were recorded between 5 to $10 \mathrm{~cm}$ in DBH in the trial (Figure 1). 


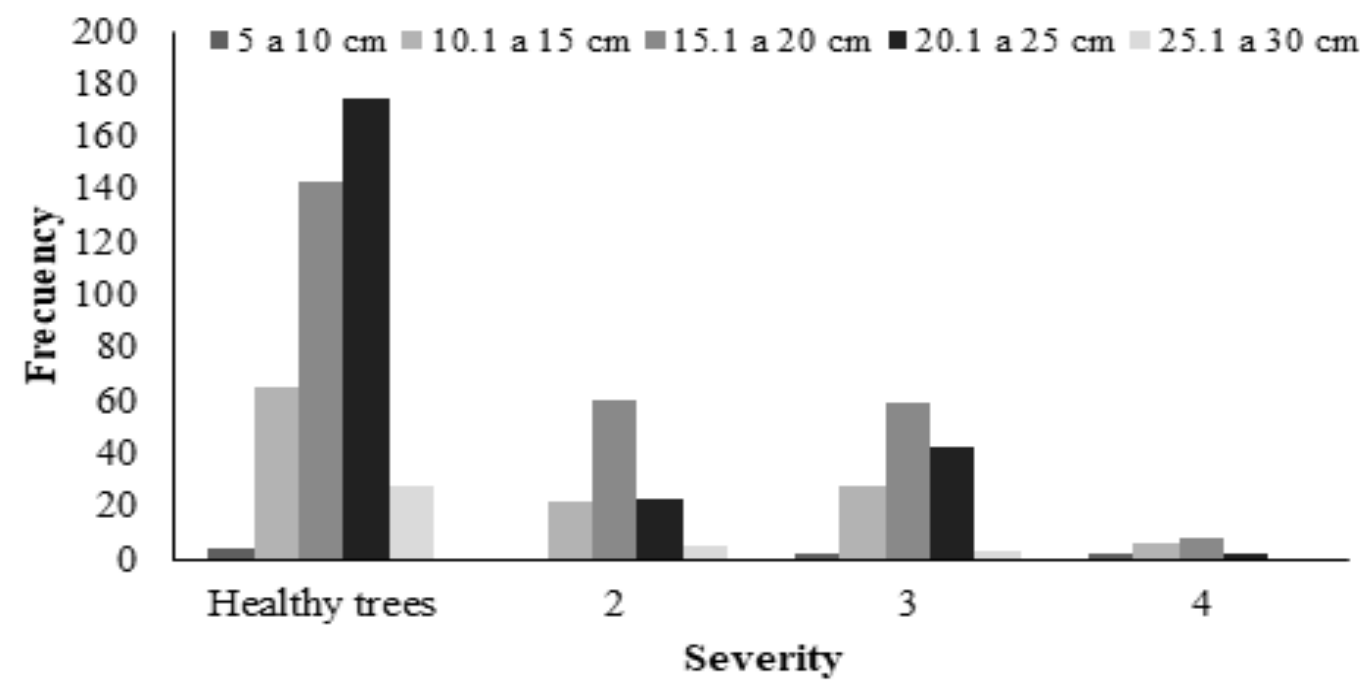

Figure 1

Diameter distribution and degree of severity associated to Ceratocystis wilt in a 2.4-year-old clonal trial of G. arborea in Guácimo, Caribbean region of Costa Rica.

When severity is combined with diameter class, it is observed that the greatest number of trees affected with severity grade 2,3 and 4 belong to the 15 to $20 \mathrm{~cm}$ diameter class. While healthy trees are mostly found in the 20 to $25 \mathrm{~cm}$ diameter class, which is above the mean diameter in the trial (Figure 1). It was also observed that trees with severity 4 predominate in the diameter classes below $15 \mathrm{~cm}$.

At 2.4 years-old, an incidence of $39 \%$, a severity index of 1.65 and a mean pathogenicity index of $21.7 \%$ were recorded. All clones recorded ramets with disease symptoms (Table 1 ). Incidence values per clone ranged from 15.8 to $68.4 \%$, while pathogenicity index ranged from 6.3 to $42.1 \%$. A group of 12 clones presented a low pathogenicity index $(<18)$, but with an incidence value reaching to $31 \%$. At the other extreme, nine highly susceptible genotypes recorded a pathogenicity index higher than $31 \%$ and with an incidence value reaching $44 \%$.

Based solely on the pathogenicity criteria, a possible selection scenario would be to take genotypes with a maximum pathogenicity index of $10.5 \%$. Thus, the resulting subpopulation would consist of the eight most tolerant genotypes, whose maximum incidence value was $30 \%$ (Table 1). However, the selection of the best materials must also consider productivity. Figure 2 shows the genetic rankings of the Pathogenicity Index and commercial volume (productivity). Here, a group of six genotypes $(57,51,1,31,19$, and 3$)$ that meet both selection criteria can be distinguished. There is another group of genotypes $(1 \mathrm{~N}, 19 \mathrm{CA}, 8 \mathrm{CA}$ and $15 \mathrm{~N})$, that rank in the first positions of productivity, but are highly intolerant to C. fimbriata.

The commercial volume genetic ranking shows little or no difference between genotypes. Therefore, some clones further down the pathogenicity index ranking, may also be selected, as shown in Figure 2.

\section{Genetic control analysis}

Individual heritability $\left(H_{g}^{2}\right)$ was very low $(<0.06)$ for all the traits evaluated (Table 2 ). While the mean clonal heritability $\left(H_{m(\text { clonal }}^{2}\right)$ showed moderate values in all traits, with the exception of severity, which registered a value of almost $60 \%$. It was also observed that the genetic variance component $\left(\sigma_{g}^{2}\right)$ exhibited a very low value in trait incidence, in contrast to the values exhibited by traits DBH, total height and severity. A higher genetic control was also determined in the severity trait than in the disease incidence, also corresponding to a higher coefficient of genetic variation ( $r=-0.346$, Table 3 ). The accuracy $(A)$ or reliability of the estimated parameters was high (> $68 \%$ ) for the severity and incidence traits, but moderate for the growth variables.

The DBH and height showed a moderate but significant genetic correlation with each other (Table 3). Both incidence and severity recorded a negative and moderate correlation with respect to tree height. Therefore, the data suggests a pattern of inverse relationship, where the smaller trees tend to show a higher rate of disease severity and incidence. While DBH shows a positive trend, although weak (not significant) in relation to both incidence and severity variables.

That is, the bigger the $\mathrm{DBH}$, the lower the incidence and severity rate. However, in Figure 1, a dominant pattern is more clearly observed, the bigger the DBH, the greater the number of healthy trees.

Table 4 shows the results of the deviance analysis (ANODEV) for both, severity and diameter among the genotypes evaluated. Here it is observed that there are highly significate differences between genotypes for disease severity, but nonsignificant differences with respect to diameter growth . 
Table 1

Incidence, severity and pathogenicity index of Ceratocystis wilt in G. arborea, in a clonal test at 2.4 years-old, Guácimo, Caribbean region of Costa Rica.

\begin{tabular}{|c|c|c|c|c|c|c|c|c|}
\hline \multirow{2}{*}{ Clone } & \multicolumn{2}{|c|}{ Incidence (\%) } & \multicolumn{4}{|c|}{ Severity grade (\%) } & \multirow{2}{*}{$\begin{array}{l}\text { Severity } \\
\text { Index }\end{array}$} & \multirow{2}{*}{$\begin{array}{c}\text { Pathogenicity } \\
\text { Index }\end{array}$} \\
\hline & Healthy & Sick & 1 & 2 & 3 & 4 & & \\
\hline 57 & 81.3 & 18.8 & 81.3 & 18.8 & 0 & 0 & 1.19 & 6.3 \\
\hline MC0814 & 81.8 & 18.2 & 81.8 & 13.6 & 4.5 & 0 & 1.23 & 7.6 \\
\hline MC0902 & 84.2 & 15.8 & 84.2 & 5.3 & 10.5 & 0 & 1.26 & 8.8 \\
\hline 51 & 71.4 & 28.6 & 71.4 & 28.6 & 0 & 0 & 1.29 & 9.5 \\
\hline 1 & 81.0 & 19.0 & 81.0 & 9.5 & 9.5 & 0 & 1.29 & 9.5 \\
\hline 53 & 70.0 & 30.0 & 70.0 & 30.0 & 0 & 0 & 1.30 & 10 \\
\hline 58 & 78.3 & 21.7 & 78.3 & 13.0 & 8.7 & 0 & 1.30 & 10.1 \\
\hline MC2402 & 84.2 & 15.8 & 84.2 & 0 & 15.8 & 0 & 1.32 & 10.5 \\
\hline 31 & 68.2 & 31.8 & 68.2 & 18.2 & 13.6 & 0 & 1.45 & 15.2 \\
\hline $32 \mathrm{PC}$ & 68.2 & 31.8 & 68.2 & 18.2 & 13.6 & 0 & 1.45 & 15.2 \\
\hline 19 & 68.8 & 31.3 & 68.8 & 12.5 & 18.8 & 0 & 1.50 & 16.7 \\
\hline 3 & 70.0 & 30.0 & 70.0 & 10.0 & 20.0 & 0 & 1.50 & 16.7 \\
\hline $35 P C$ & 59.1 & 40.9 & 59.1 & 27.3 & 13.6 & 0 & 1.55 & 18.2 \\
\hline $\mathrm{T}$ & 66.7 & 33.3 & 66.7 & 11.1 & 22.2 & 0 & 1.56 & 18.5 \\
\hline 59 & 63.2 & 36.8 & 63.2 & 15.8 & 21.1 & 0 & 1.58 & 19.3 \\
\hline MC1313 & 63.2 & 36.8 & 63.2 & 15.8 & 21.1 & 0 & 1.58 & 19.3 \\
\hline $26 P C$ & 55.0 & 45.0 & 55.0 & 30.0 & 15.0 & 0 & 1.60 & 20 \\
\hline $5 N$ & 61.9 & 38.1 & 61.9 & 14.3 & 23.8 & 0 & 1.62 & 20.6 \\
\hline 24 & 60.0 & 40.0 & 60.0 & 15.0 & 25.0 & 0 & 1.65 & 21.7 \\
\hline $18 \mathrm{PC}$ & 60.0 & 40.0 & 60.0 & 15.0 & 25.0 & 0 & 1.65 & 21.7 \\
\hline MC3204 & 52.6 & 47.4 & 52.6 & 26.3 & 21.1 & 0 & 1.69 & 22.8 \\
\hline $12 \mathrm{PC}$ & 47.6 & 52.4 & 47.6 & 33.3 & 19 & 0 & 1.71 & 23.8 \\
\hline $33 P C$ & 60.0 & 40.0 & 60.0 & 15.0 & 15 & 10 & 1.75 & 25.0 \\
\hline $20 C A$ & 57.9 & 42.1 & 57.9 & 15.8 & 15.8 & 10.5 & 1.79 & 26.3 \\
\hline 4 & 61.1 & 38.9 & 61.1 & 11.1 & 11.1 & 16.7 & 1.83 & 27.8 \\
\hline 27 & 63.2 & 36.8 & 63.2 & 0 & 26.3 & 10.5 & 1.84 & 28.1 \\
\hline $19 C A$ & 53.3 & 46.7 & 53.3 & 6.7 & 33.3 & 6.7 & 1.93 & 31.1 \\
\hline $4 C A$ & 38.9 & 61.1 & 38.9 & 27.8 & 33.3 & 0 & 1.94 & 31.5 \\
\hline 26 & 55.6 & 44.4 & 55.6 & 5.6 & 27.8 & 11.1 & 1.95 & 31.5 \\
\hline 33 & 47.4 & 52.6 & 47.4 & 10.5 & 42.1 & 0 & 1.95 & 31.6 \\
\hline $8 C A$ & 43.8 & 56.3 & 43.8 & 25.0 & 18.8 & 12.5 & 2.00 & 33.3 \\
\hline $1 \mathrm{~N}$ & 40.0 & 60.0 & 40.0 & 15.0 & 45.0 & 0 & 2.05 & 35.0 \\
\hline $24 C A$ & 40.0 & 60.0 & 40.0 & 20.0 & 30.0 & 10 & 2.10 & 36.7 \\
\hline $15 \mathrm{~N}$ & 40.0 & 60.0 & 40.0 & 6.7 & 53.3 & 0 & 2.13 & 37.8 \\
\hline 20 & 31.6 & 68.4 & 31.6 & 21.1 & 36.8 & 10.5 & 2.26 & 42.1 \\
\hline Mean & 60.8 & 39.2 & 60.8 & 16.0 & 20.3 & 2.8 & 1.65 & 21.7 \\
\hline
\end{tabular}




\begin{tabular}{|c|c|c|c|}
\hline Clone & $\begin{array}{c}\text { Pathogenicity } \\
\text { Index }\end{array}$ & Clone & $\begin{array}{c}\text { Commercial } \\
\text { Volume }\end{array}$ \\
\hline 57 & 6.3 & 51 & 0.245 \\
\hline MC0814 & 7.6 & IN & 0.243 \\
\hline MC0902 & 8.8 & 24 & 0.243 \\
\hline 51 & 9.5 & $19 \mathrm{CA}$ & 0.242 \\
\hline 1 & 9.5 & 19 & 0.239 \\
\hline $\mathbf{5 3}$ & 10,0 & 31 & 0.237 \\
\hline 58 & 10.1 & 57 & 0.236 \\
\hline $\mathrm{MC2402}$ & 10.5 & $8 \mathrm{CA}$ & 0.235 \\
\hline 31 & 15.2 & $15 N$ & 0.234 \\
\hline $32 \mathrm{PC}$ & 15.2 & $24 \mathrm{CA}$ & 0.231 \\
\hline 19 & 16.8 & MC3204 & 0.231 \\
\hline 3 & 16.7 & 3 & 0.228 \\
\hline $35 \mathrm{PC}$ & 18.2 & 59 & 0.228 \\
\hline $\mathrm{T}$ & 18.5 & $33 \mathrm{PC}$ & 0.228 \\
\hline 59 & 19.3 & $4 \mathrm{CA}$ & 0.227 \\
\hline MC1313 & 19.3 & $35 \mathrm{PC}$ & 0.226 \\
\hline $26 \mathrm{PC}$ & 20.0 & $18 \mathrm{PC}$ & 0.226 \\
\hline $5 \mathrm{~N}$ & 20.6 & 27 & 0.225 \\
\hline 24 & 21.7 & $5 \mathrm{~N}$ & 0.224 \\
\hline $18 \mathrm{PC}$ & 21.7 & $\mathrm{MC2} 402$ & 0.223 \\
\hline MC3204 & 22.8 & 1 & 0.223 \\
\hline $12 \mathrm{PC}$ & 23.8 & $\mathrm{MC0814}$ & 0.223 \\
\hline $33 \mathrm{PC}$ & 25.0 & 26 & 0.223 \\
\hline $20 \mathrm{CA}$ & 26.3 & 58 & 0.221 \\
\hline 4 & 27.8 & 4 & 0.221 \\
\hline 27 & 28.1 & $12 \mathrm{PC}$ & 0.221 \\
\hline $19 \mathrm{CA}$ & 31.1 & $26 \mathrm{PC}$ & 0.218 \\
\hline $4 \mathrm{CA}$ & 31.5 & 53 & 0.218 \\
\hline 26 & 31.5 & 20 & 0.215 \\
\hline 33 & 31.6 & $20 \mathrm{CA}$ & 0.214 \\
\hline $8 \mathrm{CA}$ & 33.3 & $\mathrm{MC} 1313$ & 0.213 \\
\hline $1 N$ & 35.0 & $\mathrm{MC0902}$ & 0.213 \\
\hline $24 \mathrm{CA}$ & 36.7 & 33 & 0.213 \\
\hline $15 N$ & 37.8 & $32 \mathrm{PC}$ & 0.213 \\
\hline 20 & 42.1 & $\mathrm{~T}$ & 0.210 \\
\hline Mean & 21.71 & Mean & 0.226 \\
\hline
\end{tabular}

Figure 2

Pathogenicity index and commercial volume genetic ranking comparison, associated to Ceratocystis wilt in a 2.4-year-old clonal trial of G. arborea in Guácimo, Caribbean region of Costa Rica. 
Table 2

Variance components and parameters in the evaluated traits associated to "Ceratocystis wilt", in a clonal test of G. arborea at 2.4 years-old, Guácimo, Caribbean region of Costa Rica.

\begin{tabular}{|c|c|c|c|c|}
\hline$\underline{\text { Parameter }}$ & $\underline{\mathrm{DBH}}$ & Total height & Severity & Incidence \\
\hline$\sigma_{g}^{2}$ & 0.3726 & 0.0824 & 0.0456 & 0.0081 \\
\hline$\sigma_{\text {plot }}^{2}$ & 0.2524 & 0.3046 & 0.0066 & 0.0018 \\
\hline$\sigma_{e}^{2}$ & 15.4389 & 4.3886 & 0.7229 & 0.2130 \\
\hline$\sigma_{p}^{2}$ & 16.0639 & 4.7756 & 0.775 & 0.2230 \\
\hline$H_{g}^{2}$ & 0.0232 & 0.0172 & 0.0588 & 0.0364 \\
\hline$H_{m(\text { clonal })}^{2}$ & 0.3522 & 0.2607 & 0.5935 & 0.4694 \\
\hline$A$ & 0.5934 & 0.5106 & 0.7704 & 0.6852 \\
\hline$C V_{g i}(\%)$ & 3.2301 & 1.9216 & 12.969 & 23.16 \\
\hline PEV & 0.2414 & 0.0609 & 0.0185 & 0.0043 \\
\hline SEP & 0.4913 & 0.2468 & 0.136 & 0.0656 \\
\hline Mean & 18.897 & 14.938 & 1.646 & 0.389 \\
\hline
\end{tabular}

$\sigma_{g}^{2}$ : genetic variance. $\sigma_{p l o t}^{2}$ : plot variance. $\sigma_{e}^{2}$ : error variance. $\sigma_{p}^{2}$ : total phenotypic variance. $H_{g}^{2}$ : individual heritability. $H_{m(\text { clonal })}^{2}$ : mean clonal heritability. $A$ : accuracy.: $C V_{g i}(\%)$ coefficient of individual genotypic variation. SEP: standard deviation. PEV: variance of the error.

Table 3

Genetic correlation matrix for variables total height, diameter at $1.3 \mathrm{~m}$, severity and incidence in a 2.4-year-old clonal trial of $G$. arborea in Guácimo, Caribbean region of Costa Rica

\begin{tabular}{|c|c|c|c|}
\hline Variable & Height & Severity & Incidence \\
\hline DBH & $0.446^{*}$ & 0.221 & 0.236 \\
\hline Height & & $-0.346^{*}$ & -0.235 \\
\hline Severity & & & $0.933^{* *}$ \\
\hline
\end{tabular}

Table 4

Analysis of deviance for diameter (DBH, above) and for severity (below) in a 2.4-year- clonal trial of G. arborea in Guácimo, Caribbean region of Costa Rica.

\begin{tabular}{|c|c|c|c|c|}
\hline Effect & Deviance & $x^{2}$ & Variance Component & Determination coefficient \\
\hline Clone & 2557.00 & 2.25 & $V g=0.3726$ & $H_{g}^{2}=0.0232$ \\
\hline Plot & \multirow{2}{*}{2554.91} & \multirow{3}{*}{0.16} & Vplot $=0.2524$ & c2plot $=0.0157$ \\
\hline Residual & & & $\mathrm{Ve}=15.4389$ & \\
\hline Full model & 2554.75 & & & \\
\hline Clone & 524.26 & $11.29 * *$ & $\mathrm{Vg}=0.0456^{* *}$ & $H_{g}^{2}=0.0588 * *$ \\
\hline Plot & \multirow{2}{*}{513.01} & \multirow{3}{*}{0.04} & Vplot $=0.0066$ & c2plot $=0.0085$ \\
\hline Residual & & & $\mathrm{Ve}=0.7229$ & \\
\hline Full model & 512.97 & & & \\
\hline
\end{tabular}

$x^{2}$ is the chi-square test, where values of 3.84 and 6.63 indicate the threshold for significance at $5 \%$ and $1 \%$, respectively, ${ }^{* *}$ indicates significant results. 


\section{Discussion}

The DBH values and total height of the trees in the clonal trial show strong growth rates, similar to those reported by Murillo et al. (2016) in a melina trail in the southern Pacific of the country. In both cases, trees above $20 \mathrm{~cm}$ diameter class recorded the highest number of healthy trees. Thus, an infection pattern inversely proportional to the DBH was observed, that is, the lower the diametric class, the higher the incidence and severity. Furthermore, the genetic correlation matrix shows a trend in this direction, with a positive relationship between both growth traits with incidence and tolerance.

This growth behavior could be associated with the effect of the disease progression, which produces a blockage of water and photosynthesis products that cannot flow through the vascular system (Arguedas et al., 2018). Finally, it manages to affect trees growth as recorded in this study. Growth rate of $\mathrm{DBH}$ in G. arborea at this age was extremely accelerated in the site conditions, where it registers values from eight to $10 \mathrm{~cm} /$ year.

Once the disease clogs the vascular system, trees will rapidly experience a decrease in growth rate, which will continue until it comes to a complete growth stop and death process occurs. The incidence (39\%) recorded in this research was higher than the value reported by Murillo et al. (2016), with $21.6 \%$ in a 2.7-year-old clonal trial in the South Pacific without thinning. A higher incidence in the Caribbean can be explained by several criteria, such as a different clonal composition used between both genetic tests and, a bigger proportion of clones highly susceptible to the pathogen.

Besides, the presence of a more aggressive (virulent) isolate of the pathogen, or the higher humidity regime in the Caribbean, may favor the spread of the pathogen. Undoubtedly, site conditions favor the appearance of this disease. The site historically registers flooding episodes that keep the water level high for prolonged periods (Arguedas et al., 2018). Salas et al. (2016a, 2016b) and Murillo et al. (2016) also reported a differential incidence rate among genotypes, in several clonal melina trials along the South Pacific of the country. While Arguedas et al. (2018) found incidence values up to $40 \%$.

Disease severity was reported from zero to $28 \%$ in commercial plantations in Costa Rica at different ages (Arguedas et al., 2018). Differences in the rate of disease severity progress was found to be dependent on the genotype (Murillo et al., 2016). Thus, severity rates of $22 \%$ found in this research are within the range reported in the country for young melina plantations. Few available studies show that site selection for plantation and genetic material, both have a significant influence on disease incidence and severity (He et al., 2016; Méndez-Báez 2011; Murillo et al., 2016; Hernández et al., 2021). In those investigations, a significant correlation between soil acidity and disease incidence was reported. Evidence suggest that a reduction of disease occurrence and severity can be achieved through better control of environmental factors, such as, avoiding water presence in the soil and controlling soil acidity by liming (Hernández et al., 2021). Disease prevention and its rate of progress can also be reduced by strict genetic selection of commercial materials, as determined in this research.

\section{Genetic control analysis}

A high genetic control was found in both traits of disease severity and incidence. High mean clonal heritability values ( $H_{m(\text { clonal })}^{2}$ ) and a significant coefficient of genetic variation were determined. Similar values were reported by Salas et al. (2016a) and Murillo et al. (2016), oscillating between 0.58 and 0.63 respectively. Individual heritability $\left(H_{g}^{2}\right)$ values were low for DBH and total height, but similar to those reported in other studies with melina. Lokmal (1994) in Malaysia, with $H_{g}^{2}$ values for DBH of 0.12 at ages 5 to 6 years, as well as in commercial height with values of $0.068,0.179$, and 0.166 at ages 1,5 , and 6 years, respectively. Hogde \& Dvorak (2004), reported heritability values for $\mathrm{DBH}$ ranging from 0.10 to 0.09 at ages 1 and 3 years, as well as in total height with values of 0.18 and 0.17 at ages 5 and 6 years. In another study in India, with 70 clones it was reported broad sense heritability for total height in 0.31 at five years-old (Kumar 2007). Finally, Hernández et al. (2021a, $2021 b)$ reported in Costa Rica values for DBH ranging from 0.068 to 0.113 at 2 to 4 years-old. Therefore, these heritability results are consistent with other studies reported with melina elsewhere.

For disease tolerance, clonal mean heritability value ( $\left.H_{m(\text { clonal })}^{2}\right)$ was higher than 0.47 and the coefficient of genetic variation over than $13 \%$. Both parameters suggest breeding potential. Through controlled crosses between the most tolerant genotypes, an improvement in the degree of tolerance would be expected (Resende et al., 2018). However, further studies are needed to address the inheritance type and an understanding of the mechanisms of Ceratocystis wilt resistance (Palloix et al., 2009).

Figure 2 supports the selection of genotypes that meet both disease tolerance and productivity criteria. None of the 34 clones registered total absence of the pathogen. However, genotypes 57, 51, MC8014, 1, MC2402, 31, 19 and 3 (eight in total), reported an incidence under $32 \%$, a pathogenicity index lower than $17 \%$ and, the best position in the genetic ranking of commercial volume (productivity). Therefore, these eight genotypes can be determined as the best option for establishing commercial plantations in the Caribbean region of the country.

The analysis of deviance shows that there are significant differences between clones with respect to disease severity, but not significant in relation to productivity. Therefore, the selection of clones for planting could be based mainly on the pathogenicity index, and more loosely on productivity. Thus, clones MC2402, MC0814, 31, 19 and 3, could be also considered for this selection, since all of them rank in the first positions with respect to the pathogenicity index (lower than 16.7). Meanwhile, their commercial volume is not significantly different with respect to the group of elite clones, positioned in the first third of the genetic ranking (Figure 2). 
The exclusive use of these materials would possibly reduce not only the incidence rate and severity of the disease, but also its rate of productivity progress in commercial plantations (Salas et al., 2016a). In addition, a well-structured thinning program could be followed to prevent the progress of the disease in plantations. In this way, melina plantations could be maintained until 5 to 6 years age, with no less than 150 standing trees per hectare, as proposed by Murillo et al. (2016).

The pathogenicity index becomes a better criterion to rank genotypes according to their degree of disease tolerance. This index not only considers the relationship presence/ absence of the disease (incidence), but also takes into account the frequency of individuals in each of the four severity categories. In this way, a weight is added that produces a better ranking of genotypes in terms of tolerance to this disease. Likewise, the pathogenicity index is based on severity values which, as a trait, recorded the highest clonal mean heritability values ( $H_{m(\text { clonal })}^{2}$ ) and a high coefficient of genetic variation (Table 2).

Therefore, it allows the construction of a better genetic ranking based on this index. The graphical approach of subdividing the genetic ranking into thirds, allows a quick visualization of the genetic structure of breeding population. A first third defines a significantly pathogen tolerant subpopulation; however, their incidence values are still relatively high, some of them are poorly productive. A better decision would be to choose a group of genotypes, whose pathogenicity index does not exceed the value of 10 , as can be seen in the first third of the ranking. This elite group would be the commercial melina subpopulation selected to establish the plantations.

It is expected, that with this reduced number of individuals, a progressive decrease in incidence will be achieved. Especially to decrease, not only the onset of the disease, but also the rate of progression through the severity categories (Murillo et al., 2016). This genetic material is expected to give us more time until the disease manifests itself. Therefore, it will allow us to follow a more relaxed plantation management, via successive thinning from the second or third year of age.

\section{Conclusions}

The pathogenicity index becomes a useful discrimination criterion for ranking genotypes for disease tolerance. Mean clonal heritability values were high for incidence and severity, evidencing that both traits are under a high genetic control. An infection pattern inversely proportional to the DBH was observed, that is, the lower the diametric class, the higher the incidence and severity. There are eight out of 34 elite clones, which show a strong genetic tolerance to the disease, and a high productivity as well. Their use can contribute to the reduction of the impact of Ceratocystis wilt in the region.

\section{Acknowledgment}

The authors thank the Research and Extension Division at Instituto Tecnológico de Costa Rica and the Forest Tree Breeding Cooperative GENFORES, for their support in the project "Development of a breeding program against diseases in teak (Tectona grandis L.) and melina (Gmelina arborea Roxb.). PHASE II. Selection and commercial reproduction of genotypes".

\section{References}

Alvarado A, Mata R, Chinchilla M (2014) Arcillas identificadas en suelos de Costa Rica a nivel generalizado durante el período 1931-2014: Il. mineralogía de arcillas en suelos con características vérticas y oxídico caoliníticas. Agronomía Costarricense 38(1), 107-131.

https://doi.org/10.15517/rac.v38i1.15161

Anuagasi CL, Onuorah JA, Okigbo RN (2017) Fungal pathogens affecting seedlings of Gmelina arborea Roxb and Tectona grandis Lf and effect of three plant extracts. International Journal of Agricultural Technology 13(3), 307330.

Arguedas M, Rodriguez-Solís M, Moya R, Berrocal A (2018) Gmelina arborea "death disease" in fast-growth plantations: Effects of soil and climatic conditions on severity and incidence and its implications for wood quality. Forest Systems 27(1), 003. https://doi.org/10.5424/fs/2018271-12236

Ávila-Arias C, Salas-Rodríguez A, Murillo-Cruz R (2016) Selección de genotipos superiores de Gmelina arborea Roxb. por su heredabilidad genética a la tolerancia de la enfermedad de pudrición del tronco, Pacífico sur de Costa Rica. Revista Forestal Mesoamericana Kurú, 13(32), pág. 11-20. https://doi.org/10.18845/rfmk.v0i0.2548

Cavallini LFA (1998) Fitopatología: un enfoque agroecológico. San José, Costa Rica. Editorial Universidad de Costa Rica. 467 pp.

Ferreira EM, Harrington TC, Thorpe DJ, Alfenas AC (2010) Genetic diversity and interfertility among highly differentiated populations of Ceratocystis fimbriata in Brazil. Plant Pathology Vol 59 (4): 721-735.

Harrington TC, Thorpe DJ, Alfenas AC (2011) Genetic variation and variation in aggressiveness to native and exotic hosts among Brazilian populations of Ceratocystis fimbriata. Phytopathology Vol 101 (5): 555-566. https://doi.org/10.1094/phyto-08-10-0228

Harrington TC, Kazmi MR, Al-Sadi AM, Ismail SI (2014) Intraspecific and intragenomic variability of ITS rDNA sequences reveals taxonomic problems in Ceratocystis fimbriata sensu stricto. Mycologia Vol 106 (2): 224-242. https://doi.org/10.3852/13-189

He DC, Zhan JS, Xie LH (2016) Problems, challenges and future of plant disease management: from an ecological point of view. Journal of Integrative Agriculture, 15 (4), 705-715. https://doi.org/10.1016/s2095-3119(15)61300-4

Hernández W, Badilla Y, Murillo O (2021a) Estimación de parámetros genéticos de Gmelina arborea Roxb. (melina) en el Caribe de Costa Rica. Uniciencia Vol. 35(1) 352-366, January-June, 2021.

Hernández W, Badilla Y, Murillo O (2021b) Selección temprana en ensayos clonales de melina (Gmelina arborea Robx.) en Costa Rica. Agronomía Mesoamericana. Volumen 32(1):93-106. https://doi.org/10.15517/am.v32i1.42069

Hernández W, Badilla Y, Esquivel E, Murillo O (2021) Comportamiento de clones de melina (Gmelina arborea Roxb.) en condiciones de suelo ácidos. Rev. Ciencias Ambientales Vol 55 (2):229-249. https://doi.org/10.15359/rca.55-2.11

Hogde GR, Dvorak WS (2004) The CAMCORE international provenance/progeny trials of Gmelina arborea: Genetic parameters and potential gain. New Forests, 28(2/3), 147-166. https://doi.org/10.1023/B:NEFO.0000040942.34566.a7

Holland LA, Lawrence DP, Nouri MT, Travadon R, Harrington TC, Trouillas FP (2019) Taxonomic revisión and multi-locus phylogeny of the North American clade of Cerarocystis Fungal Systematics and Evolution Jun (3): 135-156. 
Kumar A (2007) Growth performance and variability in different clones of Gmelina arborea (Roxb.). Silvae Genetica, 56(1-6), 32-36. https://doi.org/10.1515/sg-2007-0005.

Lokmal N (1994) Genetic parameters of Gmelina arborea: Height and diameter growth. J. Trop.For. Sci. 7(2):323 - 331.

Méndez-Báez A (2011) Evaluación de tratamientos para el manejo de Nectria sp. en plantaciones de Gmelina arborea en Santa Rosa de Pocosol, Alajuela. Tesis. Licenciatura en Ingeniería Forestal. Instituto Tecnológico de Costa Rica. Cartago, Costa Rica. 39p

Méndez Álvarez D, Tonimara de Souza C, Couto Alfenas A, Murillo O, Badilla Y, Ferreira Alfenas R (2020) First report of Ceratocystis fimbriata causing wilt on Gmelina arborea in Costa Rica. Forest Pathology. doi.org/10.1111/ efp.12628

Moya R (2004) Gmelina arborea en Costa Rica. Bois et Forest Des Tropiques, 279(1). 47-57.

Murillo O, Salas A, Murillo R, Ávila-Arias C (2016) Tasa de avance de la pudrición del tronco en melina (Gmelina arborea Roxb.) y posibilidades de manejo. Revista Forestal Mesoamericana Kurú 13 (32): 40-50. doi:10.18845/rfmk. v0i0.2551

Murillo O, Resende MDV de, Badilla Y, Gamboa JP (2019) Genotype by environment interaction and selection in teak (Tectona grandis L.) in Costa Rica. Silvae Genetica. (68):116-121. https://doi.org/10.2478/sg-2019-0020

Oliveira LS, Harrington TC, Ferreira MA, Damacena MB, Al-Sadi AM, Al-Mahmooli $\mathrm{IH}$, Alfenas AC (2015) Species or genotypes? Reassessment of four recently described species of the Ceratocystis wilt pathogen, Ceratocystis fimbriata, on Mangifera indica. Phytopathology, 105(9), 1229-1244. https://doi.org/10.1094/phyto-03-15-0065-r

Palloix A, Ayme V, Moury B (2009) Durability of plant major resistance genes to pathogens depends on the genetic background, experimental evidence and consequences for breeding strategies. New Phytologist 183(1): 190199.

Pathala D, Harini A, Hegde PL (2015) A review on gambhari (Gmelina arborea Roxb.). Journal of Pharmacognosy and Phytochemistry 4(2).

Resende MDV de (2016) Software Selegen-REML/BLUP: a useful tool for plant breeding. Crop Breeding and Applied Biotechnology - 16: 330-339. https://doi.org/10.1590/1984-70332016v16n4a49

Resende MDV, Murillo O, Badilla Y (2018) Genética Cuantitativa y Selección en el Mejoramiento Forestal. Editorial Tecnológica de Costa Rica. Cartago, Costa Rica. 302 pp.

Salas A, Murillo O, Murillo-Cruz R, Ávila-Arias (2016a) Evidencia de tolerancia genética a la pudrición del tronco en clones de Gmelina arborea Roxb. en Costa Rica. Revista Forestal Mesoamericana Kurú 13(32): 30-39. https://doi.org/10.18845/rfmk.v0i0.2550

Salas A, Murillo O, Murillo R, Ávila-Arias C, Mata X (2016b) Evaluación de la severidad de la pudrición del tronco en Gmelina arborea Roxb. Revista Forestal Mesoamericana Kurú 13(32): 01-10.

https://doi.org/10.18845/rfmk.v0i0.2547

Telford A, Cavers S, Ennos RA, Cottrell JE (2014) Can we protect forests by harnessing variation in resistance to pests and pathogens? Forestry: An International Journal of Forest Research 88(1): 3-12.

https://doi.org/10.1093/forestry/cpu012

Valdetaro DCOF, Oliveira LSS, Guimaraes LMS, Harrington TC, Ferreira MA, Freitas RG, Alfenas AC (2015). Genetic variation, morphology and pathogenicity of Ceratocystis fimbriata in Hevea brasiliensis in Brazil. Tropical Plant Pathology, 40(3), 184-192. http://dx.doi.org/10.1007/s40858-015-0036-6. 